Економічні науки: збірник наукових праць Луиького національного технічного університету. Серія "Регіональна економіка". Випуск 17 (67). Редкол.: відп. ред. к.е.н., професор І.В. Кривов'язюк. Луиьк: ІВВ Луцького НТУ, 2020. 348 с.

УДК 331.522.4

Шубала I.В., к.е.н., доцент

Луцький національний технічний університет

\title{
СУТЬ, СКЛАДОВІ ТА ФАКТОРИ ФОРМУВАННЯ КАДРОВОГО ПОТЕНЦІАЛУ ПІДПРИЄМСТВА
}

Мета дослідження полягає у вивченні суті, складових та факторів формування кадрового потенціалу підприємства. Зроблено висновок, що кожному підприємству доцільно обгрунтувати заходи щодо підвищення ефективності використання кадрового потенціалу, а також затвердити програму професійного розвитку працівників та представити детальний план витрат на вдосконалення кадрового забезпечення.

Ключові слова: кадровий потенціал, працівники, підприємство, праця, здібності персоналу.

Shubala I.V.

\section{THE ESSENCE, COMPONENTS AND FACTORS OF FORMATION OF HUMAN RESOURCES OF THE ENTERPRISE}

Solving the problem of improving the efficiency of human resources in domestic enterprises is especially important in the current difficult conditions of statehood. After all, the results of its economic activity in the future depend on the human potential of the enterprise. Therefore, a comprehensive analysis and evaluation of the effectiveness of human resources is important for the development of the economy of the enterprise and the region as a whole, given the need to implement anti-crisis development strategy in accordance with the difficult economic conditions of the country.

The main purpose of the study is to study the nature, components and factors shaping the human resources of the enterprise. On the basis of generalization of 
Економічні науки: збірник наукових праць Луиького національного технічного університету. Серія "Регіональна економіка". Випуск 17 (67). Редкол.: відп. ред. к.е.н., професор І.В. Кривов’язюк. Луцьк: ІВВ Луцького НТУ, 2020. 348 с.

approaches of scientists to understanding of the maintenance of personnel potential, according to the author under this concept it is necessary to understand set of shots of the enterprise which are characterized by a complex of individual physical and spiritual qualities, collective spirit, have certain qualification, passed previous professional training and experience in a particular field of activity, which are able to solve problems of a certain level of complexity and are the main driving force to ensure the effective functioning of the enterprise.

The following factors influencing human resources are identified: demographic, educational, motivational and social. The components of human resources should include: psychophysiological, qualification, personal. We can also identify approaches to the systematization of the results of research of human resources: resource, factor, system, functional, effective and innovative.

In general, it was found that the assessment of personnel can be based on the following areas: staffing in general and by management levels; staff trained in accordance with the requirements of the activity; the staff is selected in accordance with the job classification; in each department of service there is a key specialist, and group potential of department allows to solve the set tasks successfully, it means that personnel potential is sufficient; the set tasks are solved optimally quickly as in working collective the optimum social and psychological climate is created, there are trust relations, partnership dominates.

Based on the results of the study of the essence, components and determining factors of the personnel potential of the sanatorium, a number of key conclusions can be drawn, which will determine the direction of further research: based on the study; on the basis of consideration of experience of formation of personnel potential in the developed countries, and also the general characteristic and the analysis of the basic indicators of work of sanatorium it is possible to substantiate conceptual bases and preconditions of increase of efficiency of use of personnel potential; based on the results of factor analysis of generalized indicators of the efficiency of the use of human resources, it is possible to justify specific measures to improve the efficiency of the use of human resources of the enterprise. abilities.

Key words: personnel potential, employees, enterprise, work, personnel

\section{Шубалая И.В. \\ СУТЬ, СОСТАВЛЯЮЩИЕ И ФАКТОРЫ ФОРМИРОВАНИЯ КАДРОВОГО ПОТЕНЦИАЛА ПРЕДПРИЯТИЯ}

Цель исследования заключается в изучении сути, составляющих и факторов формирования кадрового потенциала предприятия. Сделан вывод, что каждому предприятию целесообразно обосновать меры по повышению эффективности использования кадрового потенциала, а также утвердить 
Економічні науки: збірник наукових праць Луиького національного технічного університету. Серія "Регіональна економіка". Випуск 17 (67). Редкол.: відп. ред. к.е.н., професор І.В. Кривов'язюк. Луиьк: ІВВ Луцького НТУ, 2020. 348 с.

программу профессионального развития работников и представить детальный план расходов на совершенствование кадрового обеспечения.

Ключевые слова: кадровый потенциал, работники, предприятие, труд, способности персонала.

Постановка проблеми у загальному вигляді і її зв'язок 3 важливими науковими та практичними завданнями. Вирішення проблеми підвищення ефективності використання кадрового потенціалу на вітчизняних підприємствах набуває особливо ваги в теперішніх складних умовах розвитку державності. Адже від того, який кадровий потенціал має підприємство, залежать результати його господарської діяльності у перспективі. Тому проведення комплексного аналізу та оцінки ефективності використання кадрового потенціалу має важливе значення для розвитку економіки підприємства та регіону в цілому, зважаючи на необхідність реалізації стратегії антикризового розвитку відповідно до складних економічних умов розвитку країни.

Аналіз останніх досліджень, у яких започатковано вирішення проблеми. Окремі наукові дослідження проблем формування кадрового потенціалу підприємства займалися багато вітчизняних учених, до яких можна віднести: Гарват О.А., Кравець I.М., Єсінова Н.I., Корінь М.В., Михайлюк О.В., Шевченко О.О., Шовкопляс О.О., Пенюк В.О., Сунцова О.О., Вовк О.М., Марчишина Ю.А., Ткаченко А.М., Шевченко О.М. та багато ін. [1-8]. Разом 3 тим, сучасна практика функціонування підприємств дає змогу констатувати, що проблеми аналізу та оцінки ефективності використання кадрового потенціалу набувають додаткової актуальності в період економічної нестабільності економіки. А тому потребують мобілізації зусиль для їх подальшого дослідження.

Цілі статті. Основною ціллю дослідження $є$ вивчення суті, складових та факторів формування кадрового потенціалу підприємства.

Виклад основного матеріалу дослідження 3 повним обгрунтуванням отриманих наукових результатів. На основі узагальнення підходів учених до розуміння змісту кадрового 
Економічні науки: збірник наукових праць Луиького національного технічного університету. Серія "Регіональна економіка". Випуск 17 (67). Редкол.: відп. ред. к.е.н., професор І.В. Кривов'язюк. Луиьк: ІВВ Луцького НТУ, 2020. 348 с.

потенціалу [1-8], на думку автора під цим поняттям потрібно розуміти сукупність кадрів підприємства, які характеризуються комплексом індивідуальних фізичних i духовних якостей, колективного духу, мають певну кваліфікацію, пройшли попередню професійну підготовку та володіють спеціальними знаннями, трудовими навичками і досвідом роботи у певній сфері діяльності, що здатні вирішувати завдання певного рівня складності та $\epsilon$ головною рушійною силою забезпечення ефективного функціонування підприємства.

Виділено такі фактори впливу на кадровий потенціал: демографічні, освітні, мотиваційні та соціальні (рис. 1). В основі демографічних факторів слід розглядати, вік, стать, сімейний стан працівників, міграцію населення. Як відомо до важких робіт у складних умовах праці неможна залучати жінок, а також не повнолітніх.

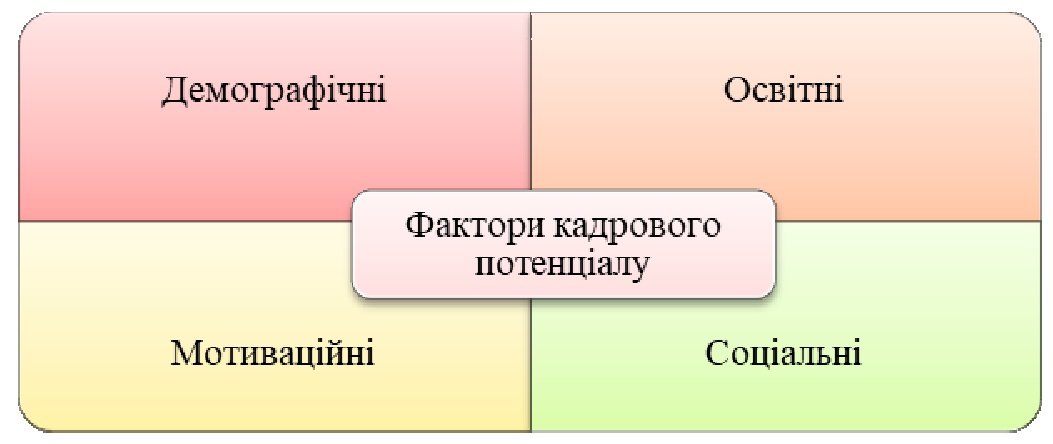

Рис. 1. Фактори впливу на кадровий потенціал (побудовано автором на основі узагальнення джерела [2])

В основі демографічних факторів слід розглядати, вік, стать, сімейний стан працівників, міграцію населення. Як відомо до важких робіт у складних умовах праці неможна залучати жінок, а також не повнолітніх.

На кадровий потенціал має також вплив і сімейний стан працівників, адже, якщо жінка є матір'ю одиначкою дитини до 14 років, то вона не може в повній мірі проявити себе, адже слід 
Економічні науки: збірник наукових праць Луиького національного технічного університету. Серія "Регіональна економіка". Випуск 17 (67). Редкол.: відп. ред. к.е.н., професор І.В. Кривов'язюк. Луиьк: ІВВ Луцького НТУ, 2020. 348 с.

більше уваги приділяти вихованню дітей, на особистий розвиток в професійному полі не вистачає часу. В той же час міграція населення на даний момент часу.

Якщо розглядати вплив міграції на формування кадрового потенціалу, то слід відмітити, що на даний момент часу значна частина кваліфікованих фахівців їде працювати за кордон, адже там на вищому рівні $є$ оплата праці ніж на даний момент в нашій державі. Це 3 року в рік набуває все більш загрозливих масштабів, що згодом призведе до закриття низки підприємств та організацій, адже працювати буде нікому. Досить швидкими темпами відбувається старінні нації, яке також має своє відображення на формуванні кадрового потенціалу, завдяки збільшенню працездатного віку на підприємствах спостерігається тенденція коли на робочих місцях працюють особи віком за 60 років, а молодь натомість працює за кордоном.

Якщо розглядати кадровий потенціал через освітню складову необхідно звернути більше уваги на професійнотехнічної освіту, адже фахівців за даними напрямками катастрофічно не вистачає в нашій державі, натомість фахівців за деякими професіями надлишок. Ми вважаємо, що повинна розроблятися стратегія підготовки кваліфікованих кадрів на основі стратегії розвитку галузей нашої держави.

Значний вплив на формування кадрового потенціалу має соціальна складова, в основі якої лежить стан здоров'я, тривалість життя, забезпеченість житлом, надання низки соціальних гарантій. На рівні підприємства основна увага має приділятися моніторингу здоров'я співробітників шляхом проведення медичних оглядів за їх рахунок, що дозволить своєчасно виявити ряд захворювань, які потребують негайного лікування.

Ще однією досить важливою складовою, яка має значний вплив на кадровий потенціал, є мотивація до праці адже саме вона спонукає до отримання максимальної віддачі від використання наявного кадрового потенціалу, що дозволяє підвищити загальну результативність і прибутковість діяльності підприємства. 
Економічні науки: збірник наукових праць Луиького національного технічного університету. Серія "Регіональна економіка". Випуск 17 (67). Редкол.: відп. ред. к.е.н., професор І.В. Кривов'язюк. Луиьк: ІВВ Луцького НТУ, 2020. 348 с.

До складових кадрового потенціалу доцільно віднести: психофізіологічну, кваліфікаційну, особистісну. Можна також виділити підходи до систематизації результатів досліджень кадрового потенціалу: ресурсний, факторний, системний, функціональний, результативний та інноваційний.

Загалом виявлено, що оцінка кадрового складу може відбувається на основі таких напрямків: кадровий склад укомплектований в цілому і за рівнями управління; персонал підготовлений відповідно до вимог діяльності; кадровий склад підібраний відповідно до класифікатора посад; в кожному відділі служби є ключовою фахівець, а груповий потенціал відділу дозволяє благополучно вирішувати поставлені завдання, це означає, що кадровий потенціал достатній; поставлені завдання вирішуються оптимально швидко, так як в робочому колективі створений оптимальний соціально-психологічний клімат, існують довірчі відносини, домінує партнерство.

Отже, кадровий потенціал є важливим та комплексним поняттям, яке відображає наявність у підприємства як окремих працівників, які мають належних рівень освіти та підготовки, так і згуртованого колективу однодумців, які здатні вирішувати поставлені перед ними завдання в контексті реалізації цілей підприємства. Під кадровим потенціалом зазвичай розуміють здібності та можливості персоналу на підприємстві, які вони можуть використовувати в певний проміжок часу для виконання конкретних завдань для перспективного розвитку підприємства, що в свою чергу має безпосередній вплив на конкурентоспроможність в цілому.

В розвинутих країнах на державному рівні $є$ підтримка вітчизняних підприємств у сфері формування кадрового потенціалу шляхом фінансової підтримки для підготовки та перепідготовки кадрів. Існує єдиний механізм взаємодії держави i підприємства за рахунок співпраці навчальних закладів 3 підприємствами на рахунок підготовки кваліфікованих кадрів в необхідній кількості, що сприяє зростанню рівня зайнятості. Для цього використовуються різноманітні інструменти взаємодії такі 
Економічні науки: збірник наукових праць Луиького національного технічного університету. Серія "Регіональна економіка". Випуск 17 (67). Редкол.: відп. ред. к.е.н., професор І.В. Кривов'язюк. Луиьк: ІВВ Луцького НТУ, 2020. 348 с.

як: ефективна податкова політика, розвиток соціально, інформаційної і правової інфраструктури.

Отже, врахування цінного зарубіжного досліду щодо формування та нарощення кадрового потенціалу має важливе значення для вітчизняних підприємств не залежно від виду економічної діяльності та форми власності. Але для цього важливе розуміння керівництва підприємства, адже цей процес передбачає додаткові вкладення у розвиток персоналу підприємства.

Для кожного підприємства доцільно обгрунтувати заходи щодо підвищення ефективності використання кадрового потенціалу, до основних з яких можна віднести: позитивний рух кадрів; підвищення кваліфікаційного рівня працівників унаслідок участі у різноманітних курсах підвищення кваліфікації та тематичних навчаннях, застосування обміну досвідом; надання консультаційних послуг щодо діяльності підприємства; підвищення освітнього рівня працівників, сприяння навчанню працівників; формування позитивної атмосфери в колективі, скорочення кількості конфліктних ситуацій.

Також важливо розробити комплекс заходів щодо планування трудової кар'єри робітників та фахівців підприємства як основи підвищення кадрового потенціалу. Кожному підприємству доцільно затвердити програму професійного розвитку працівників та представити детальний план витрат на вдосконалення кадрового забезпечення.

Висновки. За підсумками дослідження суті, складових та визначальних факторів формування кадрового потенціалу санаторію можна сформувати ряд ключових висновків, які визначатимуть напрямок проведення подальшого дослідження:

- на основі дослідження підходів до оцінки кадрового потенціалу господарюючих суб'єктів можливо провести аналіз зміни кількісних та якісних характеристик кадрового потенціалу кожного підприємства;

- на основі розгляду досвіду формування кадрового потенціалу в розвинутих країнах, а також загальної 
Економічні науки: збірник наукових праць Луиького національного технічного університету. Серія "Регіональна економіка". Випуск 17 (67). Редкол.: відп. ред. к.е.н., професор І.В. Кривов'язюк. Луиьк: ІВВ Луцького НТУ, 2020. 348 с.

характеристики та аналізу основних показників роботи санаторію можливо обгрунтувати концептуальні засади та передумовами підвищення ефективності використання кадрового потенціалу;

- на основі результатів факторного аналізу узагальнюючих показників ефективності використання кадрового потенціалу можливо обгрунтувати конкретні заходи щодо підвищення ефективності використання кадрового потенціалу підприємства.

\section{Список бібліографічного опису}

1. Гарват О.А., Кравець I.М. Сучасні підходи до управління кадровим потенціалом підприємств. Науковий вісник Полтавського університету економіки і торгівлі. Сер.: Економічні науки. 2013. № 1. С. 153-158.

2. Єсінова Н.І. Економіка праці та соціально-трудові відносини : навч. посіб. К. : Кондор, 2004. 432 с.

3. Корінь М.В., Шевченко О.О., Шовкопляс О.О. Управління розвитком кадрового потенціалу підприємств в сучасних умовах. Вісник економіки транспорту і промисловості. 2017. № 60. С. 238-245.

4. Михайлюк О.В. Сутність та складові кадрового потенціалу підприємства. Актуальні проблеми права: теорія $і$ практика. 2013. № 28. C. 411-421.

5. Пенюк В.О. Проблеми та перспективи розвитку кадрового потенціалу на сучасних підприємствах. Вісник Чернівецького торговельноекономічного інституту. Економічні науки. 2016. Вип. 3-4. С. 159-169.

6. Сунцова О.О., Вовк О.М., Марчишина Ю.А. Підприємницькі технології управління кадровим потенціалом. Міжнародний науковий журнал «Інтернаука». Серія : Економічні науки. 2018. № 2. С. 85-90.

7. Ткаченко А.М. Зарубіжний досвід формування кадрового потенціалу. Вісник економічної науки Украӥни. 2015. № 1. С. 141-146.

8. Шевченко О.М. Формування та ефективність використання кадрового потенціалу. Публічне адміністрування: наукові дослідження та розвиток. 2017. № 2. С. 55-62.

\section{References}

1. Harvat O.A., Kravets' I.M. (2013). Suchasni pidkhody do upravlinnya kadrovym potentsialom pidpryyemstv [Modern approaches to personnel potential management of enterprises]. Naukovyy visnyk Poltavs'koho universytetu ekonomiky $i$ torhivli. Seriya: Ekonomichni nauky - Scientific Bulletin of Poltava University of Economics and Trade. Series: Economic Sciences, 1, 153-158. [in Ukrainian].

2. Yesinova N.I. (2004). Ekonomika pratsi ta sotsial'no-trudovi vidnosyny [Labor economics and social-labor relations]. Kyyiv: Kondor, 432 p. [in Ukrainian].

3. Korin' M.V., Shevchenko O.O., Shovkoplyas O.O. (2017). Upravlinnya rozvytkom kadrovoho potentsialu pidpryyemstv $\mathrm{v}$ suchasnykh umovakh 
Економічні науки: збірник наукових праць Луиького національного технічного університету. Серія "Регіональна економіка". Випуск 17 (67). Редкол.: відп. ред. к.е.н., професор І.В. Кривов'язюк. Луиьк: ІВВ Луцького НТУ, 2020. 348 с.

[Management of development of personnel potential of the enterprises in modern conditions]. Visnyk ekonomiky transportu i promyslovosti - Bulletin of Transport Economics and Industry, 60, 238-245. [in Ukrainian].

4. Mykhaylyuk O.V. (2013). Sutnist' ta skladovi kadrovoho potentsialu pidpryyemstva [The essence and components of the human resources of the enterprise]. Aktual'ni problemy prava: teoriya i praktyka - Current issues of law: theory and practice, 28, 411-421. [in Ukrainian].

5. Penyuk V.O. (2016). Problemy ta perspektyvy rozvytku kadrovoho potentsialu na suchasnykh pidpryyemstvakh [Problems and prospects of human resources development at modern enterprises]. Visnyk Chernivets'koho torhovel'noekonomichnoho instytutu. Ekonomichni nauky - Bulletin of the Chernivtsi Trade and Economic Institute. Economic sciences, 3-4, 159-169. [in Ukrainian].

6. Suntsova O.O., Vovk O.M., Marchyshyna YU.A. (2018). Pidpryyemnyts'ki tekhnolohiyi upravlinnya kadrovym potentsialom [Entrepreneurial technologies of human resources management]. Mizhnarodnyy naukovyy zhurnal «Internauka». Seriya: Ekonomichni nauky - International scientific journal "Internauka". Series: Economic Sciences, 2, 85-90. [in Ukrainian].

7. Tkachenko A. M. (2015). Zarubizhnyy dosvid formuvannya kadrovoho potentsialu [Foreign experience of personnel potential formation]. Visnyk ekonomichnoyi nauky Ukrayiny - Bulletin of Economic Science of Ukraine, 1, 141146. [in Ukrainian].

8. Shevchenko O. M. (2017). Formuvannya ta efektyvnist' vykorystannya kadrovoho potentsialu [Formation and efficiency of use of personnel potential]. Publichne administruvannya: naukovi doslidzhennya ta rozvytok - Public administration: research and development, 2, 55-62. [in Ukrainian]. 